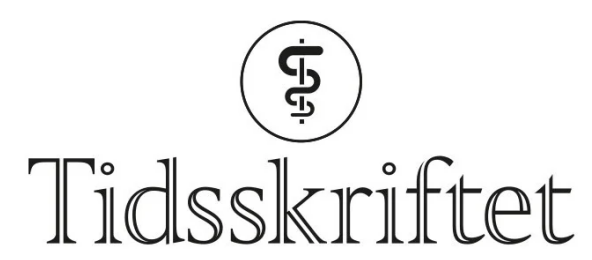

DEN NORSKE LEGEFORENING

\title{
Den norske arbeidslivsmodellen fremmer god helse
}

KRONIKK

\section{STEFFEN TORP}

steffen.torp@usn.no

Steffen Torp er professor i helsefremmende arbeid ved Forskningsgruppe for helsefremmende arbeid i nærmiljø, Institutt for helse-, sosial- og velferdsfag, Universitetet i Sørøst-Norge. Han har mange års erfaring fra arbeid $i$ bedriftshelsetjenesten som bedriftsfysioterapeut og arbeids- og organisasjonspsykolog.

Forfatteren har fylt ut ICMJE-skjemaet og oppgir ingen interessekonflikter.

\section{JON REIERSEN}

Jon Reiersen er førsteamanuensis i samfunnsøkonomi ved USN Handelshøyskolen, Universitetet i Sørøst-Norge. Han forsker og underviser i makroøkonomi, arbeidsmarkedsøkonomi, inntektsfordeling og atferdsøkonomi.

Forfatteren har fylt ut ICMJE-skjemaet og oppgir ingen interessekonflikter.

Bedriftsleger og andre i bedriftshelsetjenesten bør engasjere seg mer i hvordan norsk arbeidsliv organiseres. 


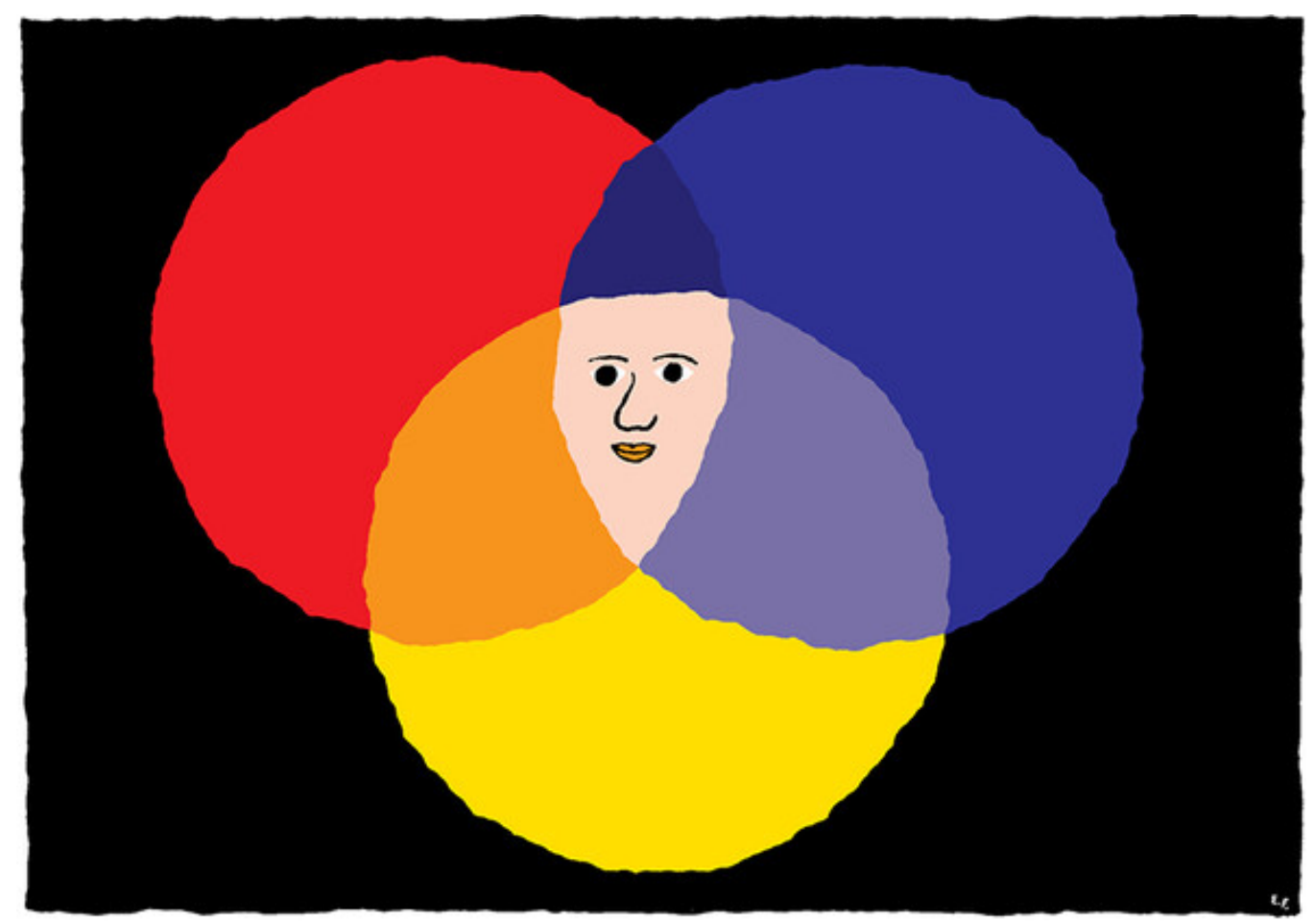

Illustrasjon: Espen Friberg

Globalisering og teknologisk utvikling skaper utfordringer for den norske arbeidslivsmodellen. Dette kan i neste omgang få konsekvenser for den norske folkehelsen. I tillegg til å arbeide med det bedriftsinterne arbeidsmiljøet bør bedriftshelsetjenesten engasjere seg i hvordan arbeidslivet organiseres.

Fougner-utvalget la i sommer fram sin rapport om framtidens arbeidsliv i Norge (1․). Overordnet handler utviklingen om økende globalisering, automatisering og nye måter å organisere arbeid og verdikjeder på. Dette vil kunne få konsekvenser for alt fra produktivitet og jobbskaping til sysselsattes rettigheter, lønnsvilkår og arbeidsrelatert helse. En nylig publisert rapport fra forskningsstiftelsen Fafo viser i den forbindelse at det har vært en økning i lavtlønte i norsk arbeidsliv og at denne økningen først og fremst kommer i virksomheter uten tariffavtaler (ㅁ$)$.

\section{Den norske arbeidslivsmodellen}

Det å være i arbeid, i kombinasjon med et godt arbeidsmiljø, har i all hovedsak en positiv innvirkning på helsen. Samtidig vet vi at et dårlig arbeidsmiljø kan føre til sykdom og helseplager. Arbeidsmiljøloven pålegger de fleste norske virksomheter å ha en bedriftshelsetjeneste som skal bistå i arbeidet med å skape et godt og helsefremmende arbeidsmiljø(3).

I et internasjonalt perspektiv har norske virksomheter, sammen med sin bedriftshelsetjeneste, bidratt til å skape gode vilkår for sine arbeidstakere (44.). For eksempel er det ingen land i Europa der de sysselsatte er mer fornøyde med arbeidsforholdene sine enn de som jobber i Norge (5). Det mekaniske og fysiske arbeidsmiljøet er godt, men det er først og fremst psykososiale faktorer som skiller arbeidsmiljøet i Norge fra det vi finner i andre europeiske land. Arbeidstakere i Norge rapporterer for eksempel om gode muligheter til å bestemme over eget arbeid og arbeidstid. De er også godt fornøyde med den sosiale støtten de făr fra kolleger og ledere, og de er fornøyde med mulighetene de gis til å lære nye ting på jobb. 
I tillegg rapporterer svært mange at de har en sikker jobb. Å ha en sikker jobb er vist å være av stor betydning for helse og livskvalitet. Til tross for forholdsvis høyt sykefravær rapporterer arbeidstakere i Norge om god mental helse og høyt jobbengasjement sammenliknet med sine europeiske kolleger (5).

Den norske arbeidslivsmodellen er kjennetegnet av et velutviklet system for samarbeid mellom arbeidsgivere, arbeidstakere og myndigheter i saker som angår arbeidslivet. Dette trepartssamarbeidet har bidratt til å skape lav ledighet, høy produktivitet, god omstillingsevne og sterk internasjonal konkurransekraft. Kombinert med forholdsvis sentraliserte og koordinerte lønnsforhandlinger har også lønnsforskjellene i Norge blitt holdt nokså moderate.

Prinsippet om solidarisk lønnspolitikk har stått sterkt i Norge. Dette går ut på å gradvis heve lønningene til dem som er på bunnen av inntektsfordelingen, mens toppen holdes tilbake. Sammen med omfordelingen av inntekt og ressurser som skjer gjennom velferdsstaten, bidrar den solidariske lønnspolitikken til å forebygge sosial ulikhet på mange plan. Små sosiale forskjeller bidrar også til at den sosiale tilliten i Norge er høy. Det er samtidig veldokumentert at land med små sosiale forskjeller og høy tillit har god folkehelse.

\section{Endret arbeidsmarked}

Vi ser nå noen utviklingstrekk som setter den norske arbeidslivsmodellen under press. Migrasjon og arbeidsinnvandring har preget det norske arbeidsmarkedet de siste 20 åra. Norge som helhet har trolig tjent på dette, men det har også skapt utfordringer. Blant annet er det vist at arbeidstakere med lav utdanning og inntekt har falt ut av arbeidsmarkedet på grunn av konkurranse med utenlandsk arbeidskraft (므).

Nært knyttet til arbeidsinnvandring er også sosial dumping og atypiske ansettelsesformer samt bruk av bemanningsbyrå, selvstendig næringsdrivende og ulike former for plattformtjenester (f.eks. Airbnb og Uber). Vi ser at utviklingen i retning av dette er sterkere internasjonalt enn det den er i Norge. Samtidig er det bransjer og virksomheter også i Norge som er sterkt berørt (4), og tematikken bør absolutt vies oppmerksomhet i tiden som kommer (7.).

Før 2000 var bruk av bemanningsbyråer forbudt i Norge. Siden da har vi sett $\emptyset$ kt bruk av bemanningsbyråer, blant annet innenfor områdene bygg og anlegg, hotell og restaurant samt helse og omsorg. Tidligere var såkalte nulltimerskontrakter vanlig, men dette ble forbudt ved lov i 2019 (med et knapt flertall i Stortinget). Bruk av innleid arbeidskraft skaper et problem for det organiserte arbeidslivet ved at det åpner for å «tøye» det eksisterende lovverket. I tillegg er det vanskelig for innleide å delta aktivt i det kollektive HMS-arbeidet i bedriften de er utleid til. Hele innleiesystemet utfordrer dessuten systemet med kollektive forhandlinger på både virksomhetsnivå og nasjonalt nivå.

I 2015 ble arbeidsmiljøloven endret slik at bedriftene fikk mulighet til å ansette flere på midlertidige arbeidskontrakter. Selv om det ikke har vært en økning i denne typer kontrakter de siste årene, mener Fougner-utvalget at denne liberaliseringen av arbeidsmiljøloven bør omgjøres. Den nye regjeringen har i Hurdalsplattformen sagt at de vil følge opp dette. I likhet med innleide fra bemanningsbyråer er det vanskelig for de med kortvarige kontrakter å ta del i HMS-arbeidet, påpeke og klage på uheldige arbeidsmiljøforhold for seg selv og andre samt å påpeke uregelmessigheter i driften av virksomheten. Midlertidig arbeid er vanlig i blant annet akademia og hotell- og restaurantbransjen. 
I forbindelse med bruk av såkalte utsendte arbeidstakere har vi sett de verste formene for sosial dumping. Utsendte arbeidstakere jobber i Norge, men har arbeidskontrakt i et annet land. Etter hvert har det blitt klart at norske arbeidsgivere skal se til at de utsendte har like vilkår som norske arbeidstakere, men systemet er vanskelig å kontrollere og utfordrer de kollektive forhandlingene og samarbeidet i det norske arbeidslivet. Utsendte arbeidstakere benyttes blant annet i bygg og anlegg.

Norge har en lav andel selvstendig næringsdrivende, kun 6-8\%. Ellers i Europa har andelen vært økende og er nå 14 \% (므). For mange virksomheter kan det være hensiktsmessig å la selvstendig næringsdrivende gjøre en del av arbeidet fordi virksomheten da ikke trenger å forholde seg til kollektivt framforhandlede lønninger, dvs. basert på tarifforhandlinger. De trenger heller ikke å betale sykepenger. Ved å sette ut (outsource) farlig arbeid til selvstendig næringsdrivende trenger virksomhetene dessuten ikke å forholde seg til strenge HMSregler.

Arbeidsmiljøloven gjelder for øvrig ikke for selvstendig næringsdrivende. Selvstendig næringsdrivende som i hovedsak gjør arbeid for én virksomhet, kalles ofte for «maskerte arbeidstakere». Det følger strenge regler for virksomheter å benytte seg av maskerte arbeidstakere, men mulighetene for mer eller mindre «kreative» løsninger er mange. Selvstendig næringsdrivende har tilsynelatende høy selvbestemmelse, men lever usikre liv når det kommer til økonomi og sosiale velferdsordninger hvis de blir syke.

I plattformøkonomien, der virksomheter og privatpersoner benytter seg av selvstendig næringsdrivendes tjenester, spiller den som ordner elektronisk kontakt mellom kunde og oppdragsgiver, en sentral rolle - ofte også i prissetting. Å få oversikt over dette arbeidsmarkedet er svært vanskelig. Det faller også utenfor det ordinære samarbeidet mellom arbeidsgiver- og arbeidstakerorganisasjonene i Norge. Plattformtjenester er for eksempel vanlig å benytte når man trenger IKT-hjelp.

\section{«Måten vi har organisert arbeidslivet $i$ Norge har vart vellykket, men nå ser vi tendenser til at systemet er $i$ endring og at kraften i den norske arbeidslivsmodellen er svekket»}

Ifølge Statistisk sentralbyrå vil så mange som en tredjedel av alle jobber forsvinne i løpet av de kommende 20 år på grunn av automatisering og digitalisering. Dette vil særlig kunne skape utfordringer for eldre arbeidstakere og de med lav og ingen utdanning. Disse gruppene vil kunne oppleve å få større problemer med å skaffe seg jobb. En annen utfordring er at nye jobber ser ut til å komme innenfor bransjer hvor fagorganisering tradisjonelt sett har stått svakt. Dette vil kunne forsterke tendensen til at færre er organisert, noe som igjen setter den norske arbeidslivsmodellen på en alvorlig prøve. Trepartssamarbeid, kollektive forhandlinger og maktbalanse i arbeidslivet forutsetter både velorganiserte arbeidsgivere og arbeidstakere.

Gjennom mange år har det utviklet seg en «norsk» ledelseskultur som bygger på dialog, tillit, medbestemmelse og konsensusorientert beslutningstaking. Med økende innslag av multinasjonale selskaper og ledere som har fått utdanning i land som USA og Storbritannia ser vi en tendens til innføring av en personalpolitikk som er annerledes enn den som er utviklet i en nordisk kontekst. Dette inntrykket bekreftes av funn fra Medbestemmelsesbarometeret, som viser at både ansatte og ledere i norsk arbeidsliv opplever at medbestemmelsesmulighetene er redusert de siste årene (9.). 
Oppsummert kan vi si at måten vi har organisert arbeidslivet i Norge har vært vellykket, men at vi nå ser tendenser til at systemet er i endring og at kraften i den norske

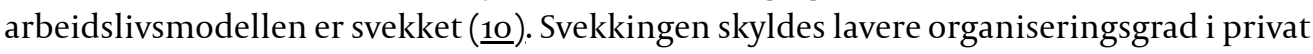
sektor, $\varnothing \mathrm{kt}$ bruk av atypiske arbeidskontrakter og en «amerikanisert» ledelseskultur som kan føre til mindre arbeidstakermakt, økt sosial ulikhet og redusert tillit. Dette vil til syvende og sist ha betydning ikke bare for de sysselsattes helse og velvære, men også for hele befolkningens helse.

\section{Bedriftshelsetjenesten bør engasjere seg}

Organisering av arbeidslivet og utforming av lovverket knyttet til arbeidskontrakter og arbeidslivsrelasjoner ligger tett opp til tradisjonell politikk, hvor venstre- og høyresiden ofte har ulike tilnærminger. Mange vil nok mene at det derfor ikke er en tematikk helsepersonell skal engasjere seg i. Likevel vet vi at politikk og organisering av samfunnet har store helsemessige konsekvenser (11), og ifølge Verdens helseorganisasjon innebærer helsefremmende arbeid å skape helsefremmende politikk (healthy public policy) kombinert med aktivt helseopplysningsarbeid.

\section{"Siden organisering av arbeidslivet og utforming av ansettelsesforhold har direkte betydning for folks helse, bør derfor dette også vcere noe bedriftshelsetjenesten skal engasjere seg $i »$}

Rettesnor for alt bedriftshelsetjenestearbeid er arbeidsmiljøloven, med dens formålsparagraf om å skape arbeid som er helsefremmende, meningsfylt og trygt, i tillegg til å sikre trygge ansettelsesforhold og likebehandling og bidra til et inkluderende arbeidsliv. Siden organisering av arbeidslivet og utforming av ansettelsesforhold har direkte betydning for folks helse, bør derfor dette også være noe bedriftshelsetjenesten skal engasjere seg $\mathrm{i}$.

Vår erfaring er at bedriftshelsetjenesten i liten grad involveres i ansettelser og hvordan virksomheter skaffer seg arbeidskraft og tjenester. Dette er selvfølgelig ledelsens og personalavdelingenes ansvar, men så lenge dette har helsemessige konsekvenser, bør det også være noe helsetjenesten er engasjert i.

Bedriftshelsetjenestens og helsepersonellets engasjement i denne tematikken kan være å løfte helsemessige problemstillinger knyttet til arbeidsliv i det offentlige ordskiftet. Minst like viktig er det $\mathrm{i}$ «helsens navn» å fremme og argumentere for lokale tiltak i de enkelte virksomheter som styrker den norske arbeidslivsmodellen gjennom fagorganisering, bruk av fast ansatte framfor innleid arbeidskraft samt å fremme en ledelseskultur som bygger på arbeidstakeres rett til medbestemmelse og delaktighet i sentrale beslutninger $\mathrm{i}$ virksomheten.

Mye bedriftshelsetjenestearbeid er anbudsutsatt. Det er forståelig at tilbydere av bedriftshelsetjeneste derfor, av frykt for å miste kontrakter, kan vegre seg for å ta opp problemstillinger som går på tvers av hva kundebedriftenes ledelse ønsker seg. Derfor mener vi at Legeforeningen, sammen med blant andre Norsk forening for arbeidsmedisin og Norsk samfunnsmedisinsk forening, bør arbeide for å bevare et godt organisert arbeidsliv og derigjennom motivere og legitimere medlemmers lokale engasjement i å

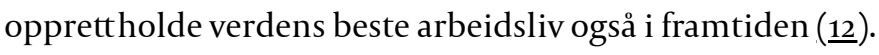

\section{LITTERATUR}

1. NOU 2021: 9. Den norske modellen og fremtidens arbeidsliv - utredning om tilknytningsformer og virksomhetsorganisering. https://www.regjeringen.no/no/dokumenter/nou-2021-9/id2862895/ Lest 
25.11.2021.

2. Jordfall B, Svarstad E, Nymoen R. Hvem er de lavtlønte? Fafo-rapport 2021: 29.

https://www.fafo.no/zoo-publikasjoner/fafo-rapporter/item/hvem-er-de-lavlonte Lest 25.11.2021.

3. LOV-2005-06-17-62. Lov om arbeidsmiljø, arbeidstid og stillingsvern mv (arbeidsmiljøloven). https://lovdata.no/dokument/NL/lov/2005-06-17-62 Lest 25.11.2021.

4. Statens arbeidsmiljøinstitutt. Faktabok om arbeidsmiljø og helse 2021. Status og utviklingstrekk. STAMI-rapport 2021. https://stami.brage.unit.no/stami-xmlui/handle/11250/2757495 Lest 25.11.2021.

5. Statens arbeidsmiljøinstitutt. Arbeidsmiljøet i Norge og EU - en sammenligning. STAMI-rapport 2017. https://stami.brage.unit.no/stami-xmlui/handle/11250/2466019 Lest 25.11.2021.

6. Hoen MF, Markussen S, Røed K. Immigration and Social Mobility. IZA Discussion Paper No. 11904. Bonn: Institute of Labor Economics, 2018. https://www.iza.org/publications/dp/11904 Lest 25.11.2021.

7. NOU 2017: 4. Delingsøkonomien - muligheter og utfordringer.

https://www.regjeringen.no/no/dokumenter/nou-2017-4/id2537495/ Lest 25.11.2021.

8. Eurostat. Taking a Look at Self-Employed in the EU. https://ec.europa.eu/eurostat/web/productseurostat-news/-/DDN-20170906-1 Lest 10.12.2021.

9. Falkum E, Ingelsrud MH, Nordrik B. Medbestemmelsesbarometeret 2016. FOU-resultat 2016: 8. https://lederne.no/wp-content/uploads/2016/11/161107-Medbestemmelsesbarometeret-2017.pdf Lest 25.11.2021.

10. Torp S, Reiersen J. Globalization, Work, and Health: A Nordic Perspective. Int J Environ Res Public Health 2020; 17: 7661. [PubMed][CrossRef]

11. Marmot M. Social determinants of health inequalities. Lancet 2005;365: 1099-104. [PubMed] [CrossRef]

12. Hvid H, Falkum E. Work and wellbeing in Nordic countries. Critical perspectives on the world's best working lives. London: Routledge, 2019.

Publisert: 10. januar 2022. Tidsskr Nor Legeforen. DOI: 10.4045/tidsskr.21.0789

Mottatt 9.11.2021, første revisjon innsendt 24.11.2021, godkjent 25.11.2021.

(C) Tidsskrift for Den norske legeforening 2023. Lastet ned fra tidsskriftet.no 26. april 2023. 